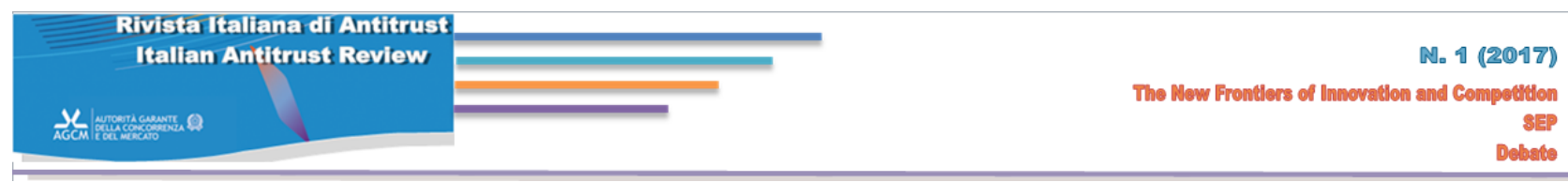

\title{
SEPs LiCENSING: A PRO-COMPETITIVE DETERMINATION OF FRAND ROYALTIES
}

\section{Gustavo Ghidini ${ }^{1}$, Giovanni Trabucco ${ }^{2}$}

Keywords: Standard essential patents; FRAND; optional standards' features; ex-ante approach; royalty stacking

\begin{abstract}
Although Courts, policy makers, academics and Standard Setting Organizations (SSOs) bave been attempting for more than a decade to substantiate the concept of fair, reasonable and non-discriminatory (FRAND) royalty terms for standard-essential patents (SEPs), so far no general organic set of basic common principles has been agreed upon. This despite the clear need of uniformity and harmonization in the standardsetting context, international by nature and participated by SSOs and stake holders from all over the world. Satisfying such need would translate in preempting risks of conflicting approaches in different regions of the world, stemming from 'technical' grounds (given the variety and diverse characteristics of both legal orders and SSOs' statutes), or fuelled by geopolitical divisions.

A three-step elastic framework of (cumulative) criteria is submitted. Its rationale is to foster dynamic competition while ensuring appropriate compensation for the innovators whose technical contributions have been declared standard-essential. This implies the acknowledgement of the superior constitutional rank of
\end{abstract}

1 Professor, University of Milan, and Luiss University, Rome.

2 Research assistant, University of Milan. the pro-competition objective, of primarily collective interest, vis-à-vis the owners' compensation, of primarily private interest. In turn, this should ultimately lead to avoid raising licensees' (implementers') costs to the point that it becomes too difficult for them to effectively compete in the market.

\section{FOREWORD}

The well-known case law concerning licensing agreements for standard-essential patents (SEPs), both in Europe - in particular, the Motorola ${ }^{3}$, Samsung and Huawei decisions ${ }^{5}$, as well as more recent ones (see below, $\int 6.4$ ) - and across the Atlantic, has coalesced into an international acquis on essential (intangible) infrastructures, whereby SEP holders have a duty to license at fair, reasonable and non-discriminatory (FRAND) terms their titles to willing licensees: even up to making, the 'owners' themselves, the 'first move' in offering such licenses ${ }^{6}$.

\footnotetext{
${ }^{3}$ Commission Decision, 29th April 2014, MotorolaEnforcement of GPRS standard essential patents, case AT.39.985.

${ }^{4}$ Commission Decision, 29 ${ }^{\text {th }}$ April 2014, SamsungEnforcement of UMTS standard essential patents, case AT.39.939.

${ }^{5}$ ECJ, 16th July 2015, Huawei Technologies Co. Ltd. v. ZTE Deutschland GmbH, case C-170/2013, in O.J. $14^{\text {th }}$ September 2015, C-302, p. 2.

${ }^{6}$ See Huawei/ZTE (fn. 5 above), \ 63 et seq.
} 


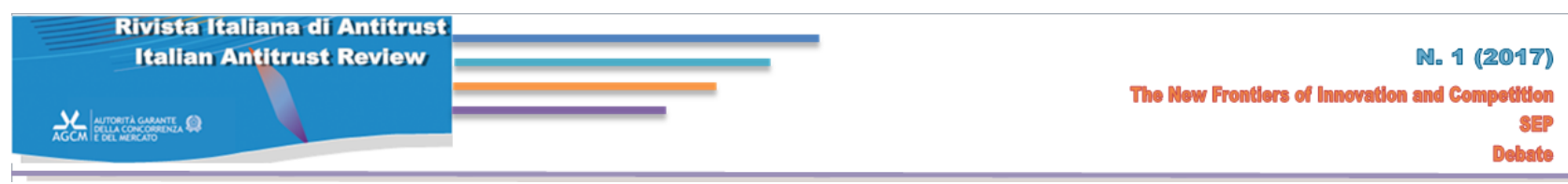

This acquis is the progeny of the original recommendations from the European Commission for adopting 'open' telecommunication standards at equitable and non-discriminatory conditions ${ }^{7}$, which proved to be a decisive tool to promote the liberalisation policy in the European telecommunications sector. The case law culminated in the affirmation, in line with the so-called essential facilities doctrine, of a duty to licence indispensable technologies that cannot be (effectively) replaced. In these cases - facing a strong risk of foreclosing competition-the statutory right to exclude deriving from the patent's ownership (or to "technology copyright", as in Microsoff $t^{8}$ ) is transformed in an adequately remunerated duty to grant access.

Historically, the basic rationale of the essential facilities doctrine (EFD) ${ }^{9}$ as applied to IP is

\footnotetext{
${ }^{7}$ See Communication from the Commission - Intellectual Property and Standardisation, COM (92)445, of 27 October 1992 and Communication from the Commission - Towards a new framework for Electronic Communications infrastructure and associated services, 1999 examination of the regulatory network for communications, 1999 Communications Review, COM (1999) 539, of 10 November 1999. See also recital 7 of Council Directive 92/38/EEC of 11 May 1992 on the adoption of standards for satellite broadcasting of television signals and recital 7 of Directive 95/47/EC of the European Parliament and of the Council of 24 October 1995 on the use of standards for the transmission of television signals.
}

${ }^{8}$ EU Tribunal, 17 Sep. 2007, Case T-201/2004, Microsoft v. Commission.

${ }^{9}$ According to the essential facilities doctrine (EFD), a monopolist who controls a facility deemed essential to compete in a given market is required to provide fair and reasonable access to the facility itself, so that (potential) competitors can join the market. On the EFD see, ex multis, R. Pitofsky, D. Patterson, J. Hooks, The essential facilities doctrine under U.S. antitrust law, in 70 Antitrust Law Journal, 2002, 443; B. DOHERTY, Just what borrowed from the parallel doctrine applied by the Commission (and earlier, by US jurisprudence of the first half of XX century) to grant access to privately owned physical infrastructures like bridges and ports ${ }^{10}$. In turn, this doctrine's basic cultural and jurispolitical roots can be traced back to Roman law on nonvoluntary servitudes. The law, in particular, whereby the owner of the only piece of land having access to a river in a given territory, had to allow neighbors access to water their cattle (servitus pecus ad acquam adpellendi), to the ultimate benefit of the agricultural economy of whole Latium ${ }^{11}$.

are essential facilities?, in 38 Common Market Law Review, 2001, 397; S.B. EVRARD, Essential facilities in the European Union: Bronner and beyond, in 10 Columbia Journal of European Law, 2004, 1; S.W. WALLER, B.M. FRISCHMANN, Revitalizing essential facilities, in 75 Antitrust L. J., 2008, 1; P. AREEDA, Essential facilities: an epithet in need of limiting principles, 58 Antitrust L. J., 841 1990, 841.

${ }^{10}$ See, on the European side: Commission Decision, $21^{\text {st }}$ December 1993, Sea Container v. Stena Sealink, case COMP IV/34.689; Commission Decision 94/119/EC, $21^{\text {st }}$ December 1993, concerning a refusal to grant access to the facilities of the port of Rodby [Denmark]; Commission Decision, 16 $6^{\text {th }}$ May 1995, Irish Continental Group/CCI Morlaix, case COMP IV/35.388. For U.S. case law, see: United States v. Terminal Railroad Association, 224 U.S. 383 (1912); Associated Press v. United States, 326 U.S. 1 (1945); Otter Tail Power Co. v. United States, 410 U.S. 366 (1973).

11 See J.M. PARDESSUS, Traité des servitudes ou services fonciers, Bruxelles, 1840. The only salient difference between the discipline of non-voluntary servitudes and the duty to grant access to an immaterial asset constituting an essential facility consists of the type and rationale of the compensation due to the 'owner'. The privileged territorial ('riverside') position of the landowner is not the fruit of his specific efforts and investments, unlike the competitive advantage acquired by the developer of a new 'irreplaceable' technology. Hence, to the former a mere indemnity for possible damages suffered from the exercise of the servitude; to 


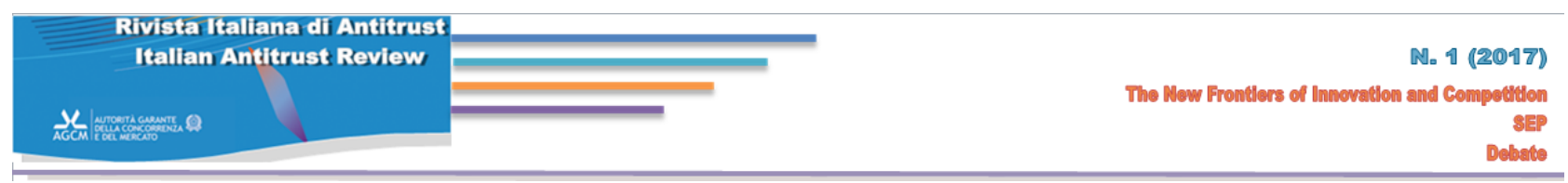

In its application to IPR protected intangibles, the EFD - carried on by well-known decisions by the Commission and the ECJ such as Magill $^{12}$, IMS Health ${ }^{13}$ and Microsoft ${ }^{14}$ - focuses on the question of whether, and to what extent, a right of access (typically in the form of a nonvoluntary licence) over innovative creations typically protected by patents or copyrights can be granted to third parties if the exercise of the excluding powers statutorily associated with IPRs might foreclose such parties from operating as effective competitors on a related downstream market or - more controversially on the same market as the technology protected by the IPR. This rests upon the economic postulate - necessary albeit not sufficient - that the IPR holder has achieved a 'plus' of foreclosing power than that inherent in the ownership of the IPR in a competitive market ${ }^{15}$, i.e. one characterized by adequate

the latter a fair compensation for allowing third parties to share the IPR protected 'top-notch' innovation.

12 ECJ, 6 Apr. 1995, joined cases C-241 and 242/1991, RTE and ITP v. Commission (so-called 'Magill' case),

${ }^{13}$ ECJ, 29 Apr. 2004, Case C-418/2001, IMS Health v. NDC Health.

${ }^{14}$ See fn. 8 above.

15 Some authors have noted that the patent notion of "monopoly" is different from that of antitrust law. In particular, R. Feldman argues that while antitrust law evokes the image of a patent holder occupying a whole competitive market to prevent competitors from entering the market, patent law merely grants the right to exclude others from using or selling the only patented invention: "all you get is the right to exclude others from standing in the sphere of the invention - as long as they do not have their own rights to be standing in that sphere as well" (See R. Feldman, Ending Patent Exceptionalism and Structuring the Rule of Reason: The Supreme Court Opens the Door for Both, in 15 Minn. J.L. Sci. \& Tech., 2014, 61, 68). In other words, substitutes of the protected technology. This postulate is based on the condition that the owned technology is 'indispensable', and thus 'essential', in the sense of 'not workably substitutable' for achieving a certain functional objective whose pursuit must be allowed to potential ${ }^{16}$ competitors. Hence it was affirmed that, in certain circumstances (defined as 'exceptional') $)^{17}$ revolving around that concept of 'indispensability', in order to avoid the occurrence of a significant distortion or even the elimination of competition ${ }^{18}$, the IPR

if there are substitutes of the patented product, there cannot be a monopoly relevant to the antitrust law. In this sense see also G. SENA, Note paradossali sulla proprietà intellettuale, in Studi di diritto industriale in onore di Adriano Vanzetti, Giuffrè, Milan, 2004, II, 1533, 1534-1535; E. ArezzO, Intellectual Property Rights at the Crossroad between Monopolization and Abuse of Dominant Position: American and European Approaches Compared, in The John Marshall Journal of Computer \& Information Law, 2006, 455, p 490-491. ; See also the authoritative opinion expressed by Judge Posner in the case Asabi Glass Co. v. Pentech Pharmacentical Ltd., 289 F. Supp. 2d 986 (2003): "if there are close substitutes of the patented product, the "monopoly" is not a monopoly in a sense relevant to antitrust law".

16 Obviously, 'exceptional' vis-à-vis the normal market framework of competition of substitutes, but in truth representing situations of foreclosure which are the normal ('mandatory' indeed) premise for antitrust intervention,

${ }^{17}$ As a matter of fact - bearing on the risk of foreclosure of competition - these are normal circumstances for legitimising the intervention of antitrust.

${ }^{18}$ In this sense, the European line appears to give priority to market protection rules over those safeguarding intellectual property, unlike the antitrust situation in the US. Note, however, that the most recent American case law has taken tentative steps in a more 'interventionist' direction: cf., for instance, the Supreme Court judgment of 19 Jun. 2013 in the case Federal Trade Commission v. Actavis Inc, 570 US, a case of 'reverse payment settlement', i.e., of the agreement under which a company pledges to pay a sum of money or other benefit 


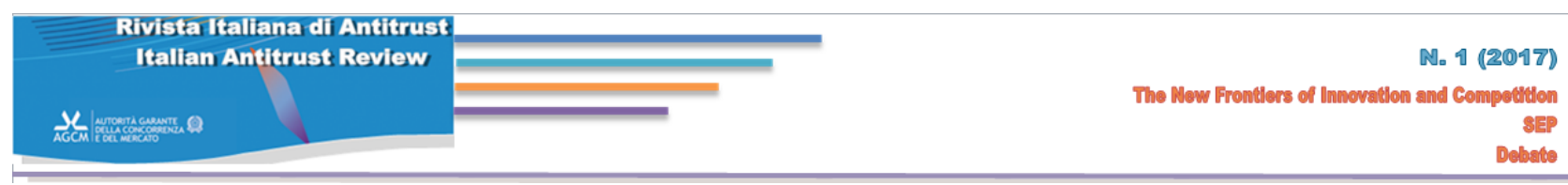

holder's power can shift from 'property' to 'liability', i.e. be bound to grant access' to third parties on FRAND terms: thus, (fairly) paying access.

\section{A BASIC PRO-COMPETITIVE RATIONALE}

The pro-competitive rationale of the duty to license SEPs at FRAND terms cannot be denied by the argument that - specifically as concerns patents that are declared essential for a "de jure standard", i.e. one that is formally established by a Standard Setting Organization (SSO) - said duty follows from patent holder's own obligation towards the SSO. As a matter of fact, the duty to license at FRAND terms is expressly imposed by European SSOs as a requirement for designating a certain technology as "standard". The Commission's guidelines on the applicability of Article 101

to its competitors to keep them from entering (or delaying their entrance on) the market. In said judgment we read that ' $[\ldots]$ These cases do not simply ask whether a hypothetically valid patent's holder would be able to charge, e.g., the high prices that the challenged patentrelated term allowed. Rather, they seek to accommodate patent and antitrust policies, finding challenged terms and conditions unlawful unless patent law policy offsets the antitrust law policy strongly favoring competition' (our italics). For analyses of the various European and US policy approaches, see K. KWOK, A New Approach to Resolving Refusal to License Intellectual Property Rights Disputes, in World Competition, 2011, 261, 263 et seq. See also E. AREZZO, Intellectual Property Rights at the Crossroad between Monopolization and Abuse of Dominant Position: American and European Approaches Compared, cit., 455; T. Kaseberg, Intellectual Property, Antitrust and Cumulative Innovation in the EU and the US, Hart, 2012, 219-235.
TFUE to the horizontal co-operation agreements of 2011, state that "to ensure effective access" to the standard, "the IPR policy [of the $\mathrm{SSO}$ ] would need to require participants wishing to have their IPR included in the standard to provide an irrevocable commitment in writing to offer to license their essential IPR to all third parties on [FRAND] terms" ${ }^{\prime 19}$.

Hence, scholars like Hanns Ullrich ${ }^{20}$ correctly draw attention to the contractual nature of the FRAND licensing commitments underttaken by SEP holders towards the SSO. In light of the ECJ Huawei/ZTE ${ }^{21}$ leading decision, Ullrich emphasizes the "self-sufficiency" under civil and commercial law principles - rather than competition law ones - of those licensing commitments where the original contractual obligation was assumed by the innovator in order to (and in exchange for) the innovator's technology being designated as standard ${ }^{22}$.

\footnotetext{
${ }^{19}$ Cf. Communication from the Commission - Guidelines on the Applicability of Article 101 of the Treaty on the Functioning of the European Union to horizontal co-operation agreements (2011/C 11/01) of 14 January 2011, par. 285 et seq.

${ }^{20}$ See H. UlLrich, FRAND Access to open standards and the patent exclusivity: Restating the principles, Max Planck Institute for Innovation \& Competition Research Paper No. 17-04, 2017, available at: https://ssrn.com/abstract $=2920660$.

${ }^{21}$ See no. 5 above.

${ }^{22}$ In the framework of the very contractual concept, the obligation imposed on the owner in relation to stating the terms of the offer at the start of negotiations is not associated with the antitrust interference in the owner's right of disposition, but rather with the application of the principles of (objective) good faith specific to contract theory, in particular, to responsibility in contrabendo.
} 


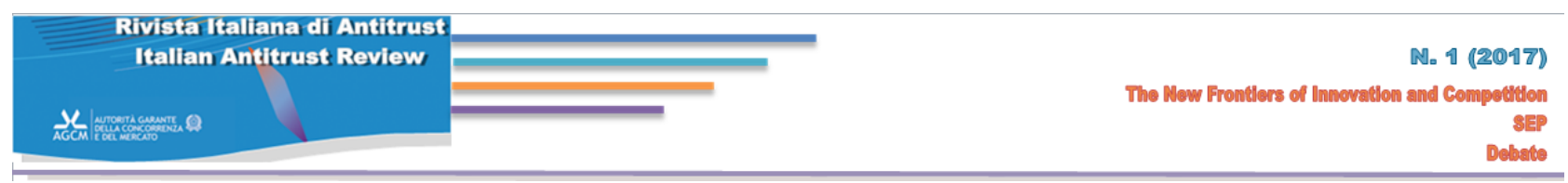

However, it must be acknowledged that the rationale behind said 'agreed' licensing committment is identical to the one underlying the EFD decisions mentioned above where, in light of the technical and commercial essentiality of a certain proprietary technology or information alone (i.e. a "de facto standard"), the courts also affirmed a duty to license ${ }^{23}$. In both situations access is to be allowed, provided an adequate remuneration is granted to the IPR holder, whereas a monopolistic position would lead to a complete foreclosure of the market concerned.

Besides, didn't the EU institutions foster a contractual trade-off - i.e. accepting a licensing duty vs. electing a certain patent as "standard" with the intent throw the door wide open to competition? So, isn't that contractual 'exchange', in fact, imposed? Indeed, if innovators do not 'voluntarily' agree to grant licenses on their IPRs at FRAND terms, or if, after their technology is 'designated' as standard, they put forward conditions that may keep competitors from entering the market, they will either see their "standard" designation revoked or a licensing agreement imposed.

In sum, licenses at FRAND terms may well be stipulated as private contracts, but under a sword of Damocles intended to safeguard an issue of public interest: protecting the competitive ecosystem of the market in question.

${ }^{23}$ See $\int 1$ above and, in particular, the cases mentioned in fn. 12, 13 and 14 above.

\section{AN ALLEGED PARADOX}

It is all too evident that the duty to licence here discussed does not sanction any tortious behaviour by the patentee. The innovator created, and patented, an invention so valuable it deserved the status of standard; and patent law grants the statutory right to exclude third parties from making use of the patented technology. But here - when the patented technology has achieved the status of standard, de iure or de facto - antitrust marches in, 'interfering' with said statutory right to exclude. Thus, that highly deserving and legitimate patent holder must give up the right that traditionally embodies the patent entitlement itself.

At first sight, this outcome seems a paradox and one of punitive flavour. The more an invention is acknowledged as top-notch, so as to be designated as standard, thus the higher the merit of the IPR holder, the less likely will he retain the (statutory) right to exclude unauthorised third parties from using the intangible asset ${ }^{24}$.

In truth, there is no paradox at all. As a matter of fact, the remuneration resulting from a (potentially unlimited) stream of royalties may well meet - or even exceed, depending on the licensees' sales prowess and success - the forecasted profits of the patent holder.

\footnotetext{
${ }^{24}$ This paradox is also noted by G. COLANGELO in $I l$ mercato dell'innovazione: brevetti, standards e antitrust (Innovation Market: Patents, Standards, and Antitrust), in Quaderni di Giurisprudenza Commerciale, 397, 2016, 64 et seq..
} 


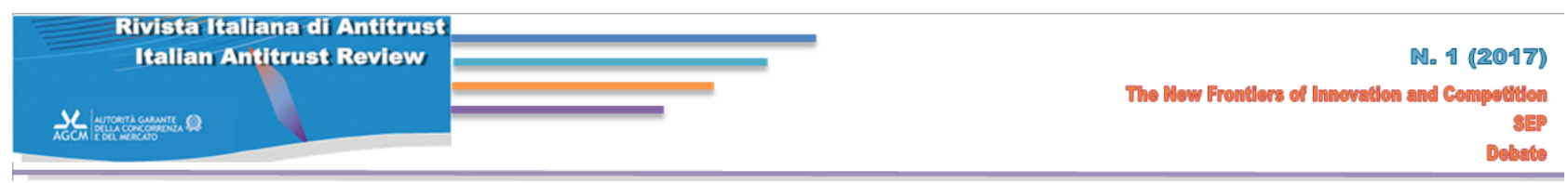

Consequently, investments in research and innovation would be incentivised. On the other side, the implementers' duty to pay the agreed FRAND royalties will usually allow the IPR holder to maintain a significant competitive advantage, as its competitors may be burdened by additional costs, the 'learning time' for using the licensed technology and, more in general, an inferior knowledge of said technology, whose potential may extend further to what is literally claimed and disclosed in the patent (also in terms of know-how) ${ }^{25}$. Besides, the patent holder can always avail for himself the possibility to access, at FRAND terms, to the

25 These considerations were first suggested and developed by W. J. BAUMOL, in The Free-Market Innovation Machine: Analyzing the Growth Miracle of Capitalism, Princeton University Press, 2002. As Baumol observes, amassing royalties can be a profitable instrument for recovering investments, so much so that in some cases it is more lucrative than exercising exclusionary rights. Baumol further notes that the licensing of a certain technology to third parties grants the owner a certain exclusive lead time over licensees because they will always need a good amount of time to properly learn how the intellectual assets work. Hence, competitors will need time to exert effective pressure on the market and the IP owner can use such time to build a good reputation (and tie consumers to its product) or improve upon its own technology, which would end up competing against the outdated version sold by the licensees. See, for example, the cited decision of the Supreme Court of US in eBay case [eBay Inc. $v$. MercExchange, L.L.C., 547 U.S. 388 (2006)] especially with reference to the concurring opinion of Justice Kennedy (joined by Justices Stevens, Souter and Breyer). With regard (also) to eBay see R. PERITZ, The Competition Question Unasked in Actavis: What Is the Scope of the Patent Right to Exclude?, 28 Antitrust, 2013, 48. See also R.P. Merges, J. M. KuHN, An Estoppel Doctrine for Patented Standards, 97 California Law Review, 2009, 28. different technologies developed by third parties, eventually on a cross-licensing basis ${ }^{26}$.

Finally, a common sense consideration. If inclusion into the standard and the FRAND licensing system were actually perceived as punitive by SEP holders, we would be at a loss to understand why would they put such efforts - over-disclosing their patents as essential ${ }^{27}$ and even trumping cards: see Rambus $\operatorname{case}^{28}$ - in

\footnotetext{
${ }^{26}$ Including beyond the provisions relating to compulsory licences for high-profile dependent innovations as per Article 31(l) of the TRIPS Agreement and Article 71 of the Italian Industrial Property Code.
}

27 The so-called over-disclosure phenomenon - i.e. claiming essentiality for a non-essential patent - is considered to be quite widespread in the TLC sector. See the study commissioned by the European Commission and drafted by researchers at the Fraunhofer Gesellshaft, K. BLIND ET AL., Study on the Interplay between Standards and Intellectual Property Rights (IPRs), Final Report, April 2001, available at

http://www.iplytics.com/download/docs/studies/ipr_st udy_final_report_en.pdf, p. 63-65. See also a number of studies conducted by Fairfield Resources International, Inc. on $3 \mathrm{G}$, GSM, WDCMA and LTE standards from 2005 to 2010, where the company reviewed the patents declared as essential for those standards, and valued that the overall percentage of essential/probably essential patents varied between 30 and 50\% (cf. http://www.frlicense.com/recent.html). Similar surveys were realized by Cyber Creative Institute Co. Ltd. in relation to the LTE standard, whereby the percentage of truly essential patents was weighed around 50\% (cf. http://www.cybersoken.com/en/research/lte/).

${ }^{28}$ The conduct of Rambus, which did not disclose the essentiality of its patents to the JEDEC standards setting organisation engaged in the development of SDRAM and DDR SDRAM specifications, was examined by the antitrust authorities, as well as European and US courts, with contradictory results. The European Commission, by its decision of 9 December 2009, Rambus, COMP/38636, C(2009) 7610, accepted the commitments proposed by Rambus, whereby the company "agrees not to charge [any royalty] for the SDRAM and DDR standards that were adopted by JEDEC during the 


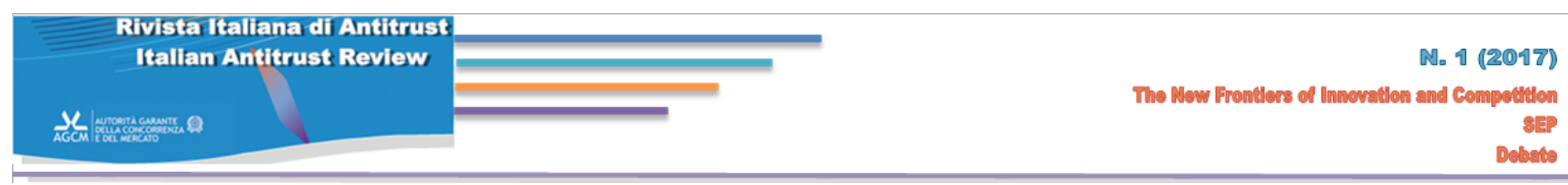

pushing their technology to be elected as standard. In fact, they fight to become, as hinted, guaranteed earners of potentially unlimited royalty streams ${ }^{29}$.

time in which Rambus was a member and engaged in its allegedly intentional deceptive conduct" and "commits to a maximum royalty rate of $1.5 \%$ for the later generations of standards adopted by JEDEC after Rambus' resignation" (section 55); see also, the parallel case in the U.S.A. where the FTC decision that established an infringement of the Sherman Act by Rambus was annulled by the Court of Appeals (D.C. Circuit), by its ruling of 22 April 2008 (522 F.3d 456), in view of the fact that the FTC "expressly left open the likelihood that JEDEC would have standardized Rambus's technologies even if Rambus had disclosed its intellectual property. Under this hypothesis, JEDEC lost only an opportunity to secure a $\mathrm{R} A N D$ commitment from Rambus. But loss of such a commitment is not a harm to competition from alternative technologies in the relevant markets" (emphasis in the original, 8).

${ }^{29}$ Finally, the FRAND system can be appreciated also under a different light. As a matter of fact, the patent holder's exclusionary power is retained (aside from diehard free riders) with respect to "average" innovation only, meaning the one that passes the non-obviousness test but does not qualify for the Oscar prize: the election as a standard. The implicit wisdom of this "discrimination" is apparent. By refraining from generalising a duty to license new technologies, the system avoids encouraging a generalised path-dependence attitude by prospective competitors. In fact, as the CFI explained: "if the mere fact of holding intellectual property rights could in itself constitute objective justification for the refusal to grant a license, the exception established by the case law could never apply. In other words, a refusal to license an intellectual property right could never be considered to constitute an infringement of Article $82 \mathrm{EC}$ even though in Magill and IMS Health [...] the Court of Justice specifically stated the contrary", cf. also Case T-201/04, Microsoft v. Commission, cit. section 690.

\section{REGULATORY NATURE OF THE DUTY TO LICENSE SEPS ON FRAND TERMS}

The SEPs/FRAND framework is thus to be read as a regulatory mechanism, designed to prevent the market foreclosure that might arise if indispensable and/or irreplaceable technologies were exploited by one party only ${ }^{30}$. A regulatory adjustment matched by the right holders' entitlement to a fair compensation.

In these instances, the term 'abuse', in the limited tool-kit of antitrust language, can only be used in a 'secondary' sense with respect to the refusal to comply with the ('primary') duty to license. The situation described is therefore quite distinct from the intrinsically illegitimate exercise of an exclusive right - for instance, to partition markets, to impose unjustifiably high prices or to obtain exclusive rights " to which [the

\footnotetext{
${ }^{30}$ In its essence, it is the approach of Article 2597 of the Italian Civil Code, affirming the duty of a legal monopolist to contract with any party requesting it, complying with the equal treatment principle: we refer to Relazione del Guardasigilli (Minister of Justice) regarding said Article, at \$1046, according to which "tal principio si impone a difesa del consumatore come necessario temperamento della soppressione della concorrenza, tenuto conto che il regime di monopolio legale, per ragioni varie e non tutte contingenti va estendendosi molto al di là di quei particolari settori (come $i$ trasporti ferroviari) nei quali tradizionalmente si soleva considerare tale fenomeno" ["such principle is introduced for consumers' protection required to mitigate the suppression of competition, taking into account that the legal monopoly regime, for a number of reasons (not all of them contingent), extends beyond particular sectors (as the railways) which were traditionally considered with regard to the said phenomenon"]. This concept, and rationale, is substantially shared by the Commission's Guidelines on horizontal co-operation agreements (fn. 19 above), where needs primarily of antitrust nature, intensified over time, imposed the mechanism of FRAND commitments.
} 


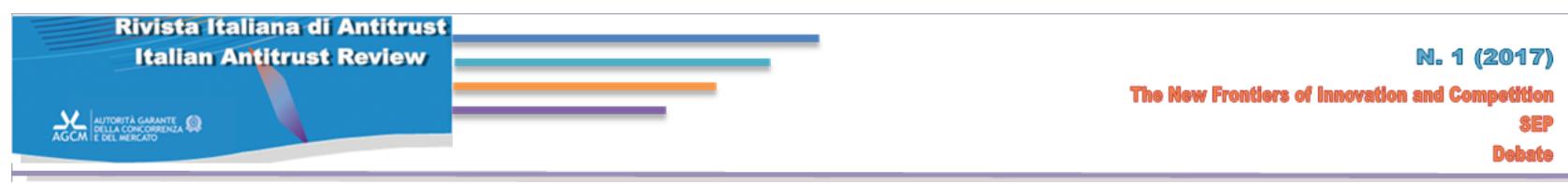

patentee] was not entitled [...] or to which it was entitled for a shorter period" (see AstraZeneca ${ }^{31}$ ). In these cases the commission of 'true' (= 'primary') abuses can well be assessed, whereas the very idea of a fair remuneration of the abusing IPR holder is inadmissible, not to say surreal.

Now, terminology is not of the essence, nor even is the consciousness of the distinction - an Authority or Court can well 'make regulation' just as Molière's M. Jourdain made prose. The distinction is relevant vis-à-vis the attraction of (legitimately acquired and statutorily exercised) IPRs' exploitation (including in the contractual disposition thereof, hence, also, the freedom to appoint and choose possible licensees) in the perimeter of the constitutionally ranking 'right to do business' (art. 16 CFREU) i.e. freedom of enterprise $^{32}$. Undisputedly indeed, the immaterial assets protected by IPRs are instruments utilized by entrepreneurs in the organization and functioning of their undertaking.

Hence, in sum, our concern is that the imposition of objective limits on the exercise economic rights of constitutional rank be designed, and 'stabilized', in its basic tenets, through an open democratic law-making

\footnotetext{
${ }^{31}$ CJEU decision of 6 December 2012, AstraZeneca v. Commission, C-457/10, ECLI:EU:C:2012:770. In this case the companies were charged with false statements made before the patent authorities in order to obtain an illegitimate extension of the patent exclusivity period.

${ }^{32}$ Let alone their intrinsic status of human rights (in so far as held and exercised by individual authors and inventors ): see art. 27(2) of the Universal Declaration of Human Rights.
}

process, rather than entrusted to the often shifting approaches and trends-not rarely driven, especially in the US experience, by the contingent political-economic Zeitgeist ${ }^{33}$-of judiciary Courts and/or administrative authorities.

\section{THE HEART OF THE MATTER TODAY: DEFINING FRAND TERMS, ROYALTIES IN PARTICULAR}

As said, the evolutionary jurisprudential path that led to substantially apply the EF doctrine to standard-essential patents, has been confirmed in its main lines in Europe and in the U.S., as well as in other major regional legal orders - such as People Republic of China's and India's - involved in the development and use of technology standards ${ }^{34}$.

\footnotetext{
${ }^{33}$ See here E. Fox, Chairman Miller, the Federal Trade Commission, Economics, and Rashomon, in Law and Contemporary Problems, 1987, 33 ss.

${ }^{34}$ The US courts and authorities distinguished themselves, firstly, by proposing among the first the "anti-injunction approach", i.e. the trend where having made FRAND commitments is incompatible with an application for an injunction regarding the activity of an (alleged) infringer ready to enter into a licence agreement (the "willing licensee" described above); and this follows an ideological approach originating from the eBay ruling of the US Supreme Court and, in particular, the concurring opinion of Justice Kennedy [eBay Inc. $v$. MercExchange, L.L.C., 547 U.S. 388 (2006)]. As an example of this approach, see the ruling of Judge Posner (afterwards partially overturned on appeal) in Apple Inc. $v$. Motorola Inc., 869 F.Supp.2d 901, 911 (N.D. Ill. 2012): “I don't see how, given FRAND, I would be justified in enjoining Apple from infringing [the patent] unless Apple refuses to pay a royalty that meets the FRAND requirement. By committing to
} 


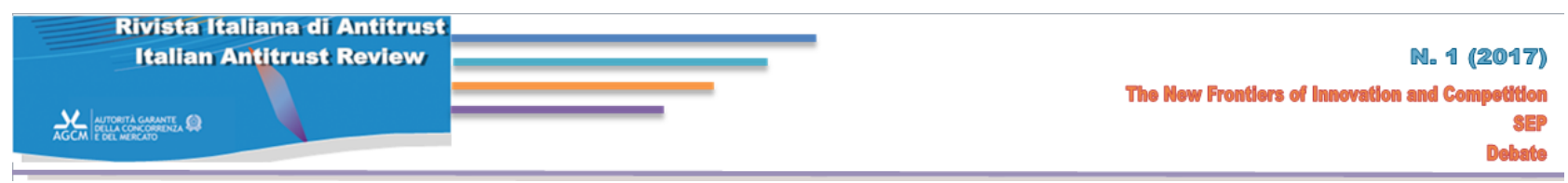

Accordingly, the 'heart of the matter'- the real focus of judges' and scholars' (as well as practitioners') attention has today shifted from the confirmation of a duty to license "essential" technologies, as a principle, to the need to

license its patents on FRAND terms, Motorola committed to license [the patent] to anyone willing to pay a FRAND royalty and thus implicitly acknowledged that a royalty is adequate compensation for a license to use that patent. How could it do otherwise? How could it be permitted to enjoin Apple from using an invention that it contends. Apple must use if it wants to make a cell phone with UMTS telecommunications capability - without which it would not be a cell phone" (emphasis in the original, 18). Further, the US courts were the first to propose the numerical determination of FRAND royalties. See an equally famous decision of Judge Robart in Microsoft Corporation v. Motorola, Inc., No. C10-1823 JLR, 2013 (W.D. Wa. 25 April 2013).

For a survey of People's Republic of China approaches to the issue of FRAND, see Y. B. LI, Antitrust Correction for Qualcomm's SEPs Package, Licensing and Its Flexibility in China, in IIC, 2016, 336; J Lee, Implementing the Frand Standard in China, in Vand. J.Ent \& Tech. L., 2016, 37; D. SOKOL, W. ZHeng, FRAND in China, in Tex. Intell. Prop. L.J., 2013-2014, 71.

As concerns Indian case law and guidelines, see $\mathrm{R}$. VISWANATH, Demystifying the Indian FRAND Regime: The Interplay of Competition and Intellectual Property, in Journal of Intellectual Property Rights, 2016, 90. The experience of India in the field of essential patents and FRAND commitments was discussed at the international conference of the Jindal Initiative on Research in IP and Competition (JIRICO) on 20-21 August 2016, organized in New Delhi by the O.P. Jindal Global University, where the authors of the present paper presented an early version of same. Recently, an accurate analysis has been provided, under appointment of the European Commission, by C. Pentheroudakis, J. C. BAron, Licensing Terms of Standard Essential Patents: A Comprehensive Analysis of Cases, JRC Science for Policy Report, EUR 208702 EN, 2017. See also B. LUNDQVIST 'The rise of standardisation and the limits to self-governance': unilateral conduct under international standards from an EU competition law perspective, in T. RIIS (ed.), User Generated Law, Edward Elgar, 2016, 180; and V. TORTI, Intellectual Property Rights and Competition in Standard Setting-Objectives and Tensions, Routledge, 2016. assess the compliance of such licences (and related procedures, see Huawei $^{35}$ ) with FRAND terms - in particular as concerns the thorny issue of the determination of royalties.

In this regard, the need for consistency with the intrinsic pro-competitive rationale of the duty to license seems all too obvious. And requires that such determination reflects and expresses an ultimately pro-competitive balance of the conflicting interests at stake: namely the right of the SEP holders ('innovators') to an appropriate remuneration ${ }^{36}$ and the right of the licensees ('implementers') to obtain access

35 See fn. 5 above.
36 'Appropriate', not maximised, borrowing, as an
indication of general scope, from the ECJ in Premiere
League Joined Cases C-403 and 429/08,
ECLI:EU:C:2011:631, Premier League Ltd v. QC Leisure
and Murphy v. Media Protection Services Ltd, 4 October
2011 , paras. 108 and 109, where the Court stated that:
"the specific subject-matter of the intellectual property does not
guarantee the right holders concerned the opportunity to demand the
bighest possible remuneration. Consistently with its specific subject-
matter, they are ensured - as recital 10 in the preamble to the
Copyright Directive and recital 5 in the preamble to the Related
Rights Directive envisage - only appropriate remuneration for each
use of the protected subject-matter". Although the decision
relates to copyright remuneration in view of the
Copyright and Related Rights Directives recitals, we see
no reason to state that this is not a general principle for
all the intellectual and industrial property rights in
general. Further, similar benchmark considerations were
made by the very ECJ in cases concerning patents for
inventions, cf. Judgment of 14 July, Merck/Stephar, C-
187/80, ECLI:EU:C:1981:180, par. 9-10 (where: "the
substance of a patent right lies essentially in according the inventor
an exclusive right of first placing the product on the market
[...which] enables the inventor, by allowing him a monopoly in
exploiting his product, to obtain the reward for his creative effort
without, however, guaranteeing that he will obtain such a reward in
all circumstances"); see also Judgment of 5 December 1996,
Merck/Primecrown, C C-267/95 and C-268/95, ECLI:EU:C:1996:468, par. 31. 


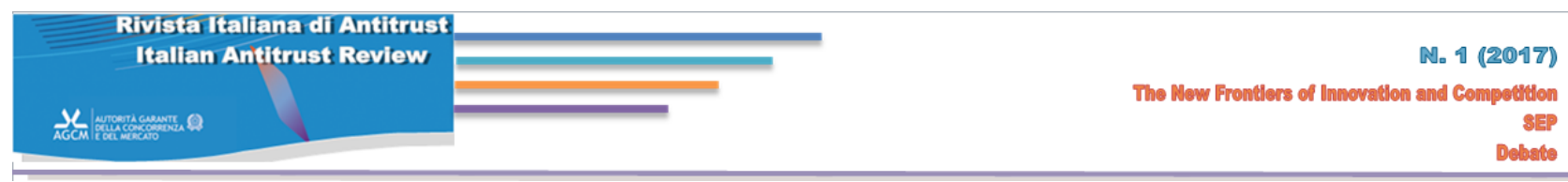

conditions allowing them effective competitiveness on the market.

\section{THREE PRO-COMPETITIVE CRITERIA FOR ASSESSING FRAND ROYALTIES}

In today's practice, FRAND terms are determined on a case-by-case basis, frequently occurring upon private agreements or arbitrations or, in default, by Courts' or Competition Authorities' individual adjudication. But the goal of ensuring an ultimately procompetitive balance of the conflicting interest at stake requires, first of all, the elaboration of basic guidelines functional thereto. Guidelines that should be incorporated in SSO's policies, and preferably also in regulatory provisions better if at international or at least regional level, and the applied in the concrete cases by Courts and/or Competition Authorities.

Providing a balanced pro-competitive playing field might contribute to avoid that the pure remittance to private agreements or to adjudications of merely individual scope might either reflect possible inequalities of bargaining power of the parties, or however translate into an Harlequin dress in clear conflict with the needs of reliability, transparency, and harmonisation of the standard-setting context ${ }^{37}$.

${ }^{37}$ In fact, full standardisation would translate in preempting risks of conflicts of approaches and decisions in different regions of the world, either stemming from 'technical' grounds (given the variety and diverse
Some criteria deemed suitable for this purpose are hereinafter submitted - focused on the purely economic determination of royalties (thus, not also on other relevant terms and conditions such as duration, termination, territorial coverage, grant-backs, and so on).

They are three, expressed as progressive, joint and cumulative steps. Of course, we are not suggesting a "magic formula" here, but a number of criteria to be taken into account for the finding - within the elastic borders of a general clause of 'fairness' - of a range of plausible licensing schemes ${ }^{38}$ amongst which the parties and, in their default, Courts and Authorities shall choose the best one for the specific case.

characteristics of SSO's), or fuelled by geopolitical divisions.

38 "Further developing FRAND as a regulatory instrument for the future of SEP licensing requires that we understand and acknowledge that FRAND, by design and by necessity, defines $\underline{a}$ range - not a rate" (emphasis added): thus a recent Report of the Joint Research Center at the European Commission, by C. Pentheroudakis, J. A. BARON, Licensing Terms of Standard Essential Patents. A Comprehensive Analysis of Cases, in JRC Science for Policy Report, EUR $28302 \mathrm{EN}$,

https:/ / ec.europa.eu/jrc/en/publication/eur-scientificand-technical-research-reports/licensing-terms-standardessential-patents-comprehensive-analysis-cases.

This approach, which was first adopted in Motorola (fn. 34 , above), seemingly diverges from that declared in the recent UK decision Unwired Planet v. Huawei [2017] EWHC 711 (Pat), 5 April 2017-the first European decision that specifically addresses the determination of FRAND royalties. Here, Briss J stated that "There is only one set of license terms which are FRAND in a given set of circumstances [...]. That way the FRAND undertaking can be enforced' (emphasis added). The injunction decision was also recently published, see Unwired Planet v. Huawei [2017] EWHC 1304 (Pat). On this decision see further $\mathrm{D}$, in this $\int$. 


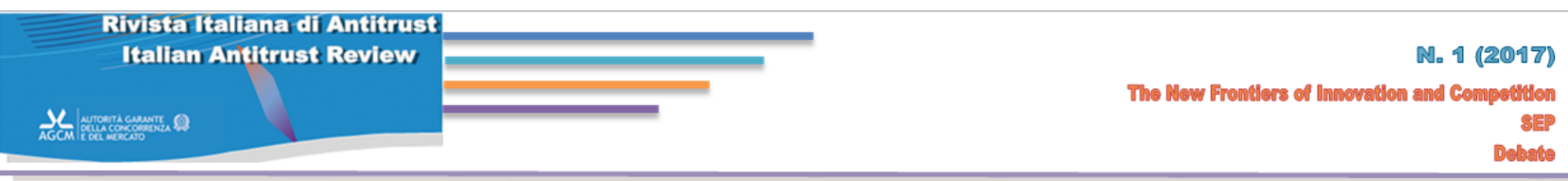

\subsection{Precise identification of the technology adopted by potential licensees, and strict proportion between the IP protected standards and such technology}

Standards are complex sets of rules. They are continuously updated and amended by working groups and dedicated experts. For instance, the well-known 3G/UMTS standard for telecommunications was improved by way of several subsequent "releases" and accounts for hundreds of technical specifications (i.e. analytical documents addressing one specific function of the system). In turn, technical specifications are commonly modified and published for every release of the standard ${ }^{39}$. As a result of such relentless activity, standards often end up comprising both newly added and optional technical features ${ }^{40}$.

\footnotetext{
39 The first version of the UMTS standard was published as "Release "99" in the early 2000s. From then on Releases 4 to 9 have been published, almost accounting for a new release every year. As to technical specifications, the one on "Spreading and modulation (TDD)", i.e. TS 25.223, for instance, was published in six different versions under release 4, namely version 4.1.0, 4.2.0 and so on (cf. http://www.3gpp.org/DynaReport/25223.htm).

The UMTS standard evolved into the LTE standard, for which Releases 10-14 have been drafted. The industry is now developing the $5 \mathrm{G}$ standards. For additional information, cf. the Third Generation Partnership Project (3GPP) at http://www.3gpp.org/.

${ }^{40}$ ETSI as well, in defining the concept of standard for its purposes, allows that it "shall mean any standard adopted by ETSI including options therein or amended versions", see ETSI Intellectual Property Rights Policy, in ETSI Rules of Procedure, Annex 6, 18 November 2015, 42. (The very UMTS standard thus allows for alternative implementation choices in the radio interface and/or optional features). See also J. P. KESAN, C. M. HAYES, FRAND's Forever: Standards, Patent Transfers, and Licensing Commitments, in Indiana Law Journal, 2014, 241,
}

Technical features may be "optional" in relation to a specific product at least in three different cases $^{41}$. In the first place, the technical specification at stake may relate only to part of the standardized system. For instance, the portions of the standard regulating the features of mobile devices may not apply to network infrastructures, and vice-versa. In the second place, a technical feature might have been added to the standard when several standardcompliant products were already in the market and, therefore, it will not be necessarily implemented by said earlier products. In the third place, a feature of the standard may be optional in the sense that the producer can freely decide whether to implement such technology or not, without affecting the product's interoperability.

Now, it is generally understood that a feature's optionality, as of itself, does not hinder the possibility for the relative patent to be essential: that patent may well be essential, but only in relation to that optional feature. This was expressly confirmed, for instance, in the Standard Board Bylaws of the IEEE which confirm that: "Essential Patent Claim' shall mean any Patent Claim the practice of which was necessary to implement either a mandatory or optional portion of a

introducing the concept of 'noncore patents', i.e. those essential patents relating to optional features.

${ }^{41}$ The examples are suggested in a report delivered under the aegis of the EUROPEAN COMMISSION, Patents and Standards, A modern framework for IPR-based standardization, Final Report, 2014, 115-116, available at http://ec.europa.eu/growth/industry/intellectualproperty/patents/standards/index_en. htm. 


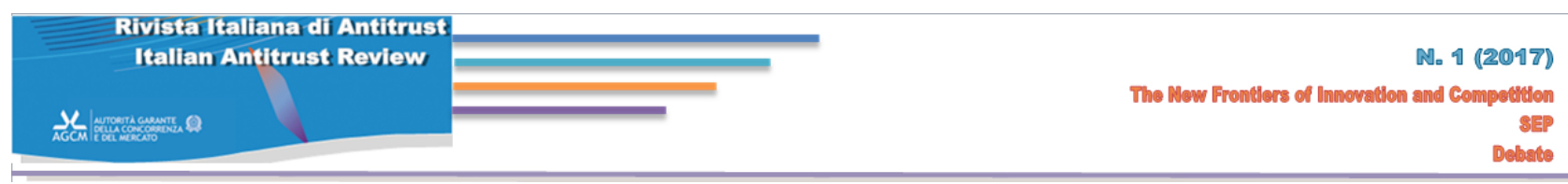

normative clause of the IEEE Standard"42. According to a 2013 study, seven of the most important SSOs include optional portions of the standard in the definition of essentiality ${ }^{43}$.

If a specific feature of the standard is indeed optional, any patent that is declared as essential for that feature might be implemented by the competitor's products placed on the market. The question remains whether it has been effectively implemented. This is decisive for the very existence of a duty to license, which is logically to be ascertained before the determination of the royalty itself. If a product does not implement a patented technology, why should the patent owner be remunerated for it?

As part of the generally recognized duty of 'fair dealing' set out by the EU Court of Justice, at the beginning of the negotiations, the SEP holder should: (i) provide to the potential licensee with the relevant "claim charts", i.e. synthetic documents showing how the SEP can

42 IEEE, IEEE-SA Standards Board Bylaws, December 2015, 15, available at

http://standards.ieee.org/develop/policies/

bylaws/index.html.

43 R. Bekkers, A. Updegrove, IPR Policies and Practices of a Representative Group of Standards-Setting Organizations Worldwide, 2012, 58, available at

http://ssrn.com/abstract $=2333445$.

However, the authors convey that there are other SSOs who do not mention distinctions between mandatory, optional and alternative elements. As Judge Robart affirms t (in Microsoft $v$. Motorola) " because an "essential" patent is one that is necessary to implement either an optional or mandatory provision of a standard, a specific SEP may contribute greatly to an optional portion of a given standard, but if that portion is not used by the implementer, the specific SEP may have little value to the implementer" be read on the technical specification of the standard; (ii) assess whether the relevant technical specifications constitute mandatory or optional portions of the standard for the products at stake; and (iii) in case they refer to merely optional portions of the standard, the SEP holder should also show how the products at stake implement those portions of the standard $^{44}$. In the latter case, however, the SEP holder shall not provide full evidence of the effective implementation for the purposes of negotiating a license, as this would likely constitute an excessive burden for him; prima facie evidence should be sufficient for the negotiation stage.

The potential licensee may then be in the position to rebut such evidence, showing that the patent(s) at stake are not implemented by its products. If the potential licensee cannot rebut the prima facie evidence submitted by the implementer, the negotiations shall move forward holding that the patents are effectively implemented (although nothing should prevent, in line with Huawei, "the alleged infringer [from] challenging, in parallel to the negotiations relating to the grant of licences, the validity of those patents and/or the essential nature of those patents to the standard in which they are included and/or their

\footnotetext{
${ }^{44}$ The Huawei/ZTE decision too, in a noteworthy passage, seems to suggest the adoption of the criterion of strict proportionality, and the placing of the burden of proof on the SEP holder, stating that before bringing an action for prohibitory injunction, a patent holder must "alert the alleged infringer of the infringement complained about by designating that SEP and specifying the way in which it has been infringed".
} 


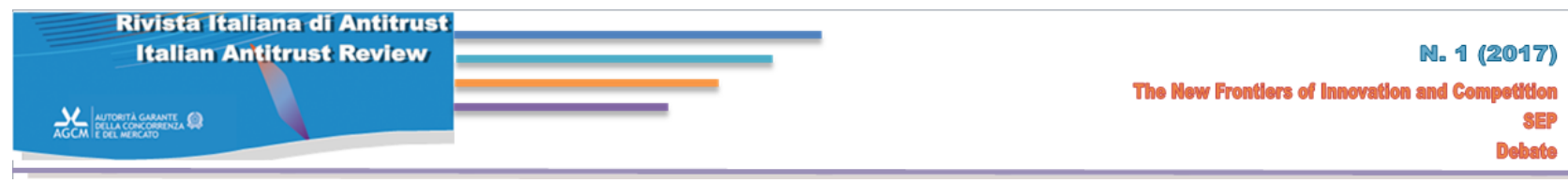

actual use, or for reserving the right to do so in the future $\left.^{\prime \prime 4}\right)$.

\subsection{Taking into account the incremental value of the patent at the time of the standard setting (ex ante assessment)}

The standard-selection process plays a fundamental role in the determination of the patent's value. Prior to the adoption of a standard, it is likely that several technological alternatives for similar features are weighed against each other by the SSO's members on the basis of their quality, their price and their added-value to the standard, in order to determine which will better fit the industry's needs.

However, when the standard is finally adopted, the owners of the IP rights covering the chosen technologies will see a dramatic increase of their patent's market power. This is because the SEPs will be implemented-within the optionality limits explained above-by every SSO participant, potentially allowing the SEP holder to extract revenues and even to "holdup" competitors with requests for supracompetitive fees paired up with the threat of an injunction ${ }^{46}$. Conversely, those patents that have not been adopted may turn out to be

\footnotetext{
45 See fn. 5 above, $\ 69$.

${ }^{46}$ Any in-depth discussion of the theory of hold-up falls outside of the scope of the present work. Basic reference is therefore made to M.A. LEMLEY, C. SHAPIRO, Patent bold-up and royalty stacking, in Texas Law Review, vol. 85, 2007, 1991; C.V. CHIEN, Holding Up and Holding Out, in Michigan Telecommunication \& Technology Law Review, 2014, 1; A. GALETOVIC, S. HABER, R. LEVINE, An empirical examination of patent boldup, in Journal of Competition Law \& Economics, 2015, 1;
}

worthless, especially if there is no market for that technology, other than the standard one ${ }^{47}$.

Against this background, the vast majority of scholars, economists and courts seem to agree on that a "reasonable" royalty should reflect only the value of the patent qua patent, and not the value associated to its inclusion in the standard $^{48}$. Swanson and Baumol were among the first scholars to suggest, in an influential article published in 2005, that "the concept of a 'reasonable' royalty for purposes of $\mathrm{R} A \mathrm{ND}$ licensing must be defined and implemented by reference to ex ante competition, i.e. competition in advance of the standard selection"49. Lemley and Shapiro also conveyed that "[b]y construction, the reasonable royalty rate does not include the value attaching to the creation and adoption of the standard itself. To allow the patentees to capture that value, which flows from the collective adoption decisions of the group rather than from the underlying value of the technology chosen,

\footnotetext{
${ }^{47}$ H. HovenKamp, Competition in Information Technologies: Standard-Essential Patents, non-practicing entities and FRAND bidding, in University of Iowa Legal Studies Research Paper, No. 12-32, available at

https://papers.ssrn.com/sol3/papers.cfm?abstract_id=2 154203, 12.

${ }^{48} \mathrm{~T}$. COTTER, The Comparative Law and Economics of Standard Essential Patents and FRAND Royalties, in 22 Texas Intellectual Property Law Journal, 2014, 311; J. LERnER, J. Tirole, Standard-Essential Patents, in Journal of Political Economy, 2015, vol. 123, no. 3, available at http://www.journals.uchicago.edu/doi/citedby/10.1086 /680995; See also R. GRASSO, Standard Essential Patents: Royalty Determination in the Supply Chain, in Journal of European Competition Law \& Practice, 2017, vol. 8, No. 5, p. 283.
}

${ }^{49}$ D. Swanson, W. BaUmOL, Reasonable and Nondiscriminatory (RAND) Royalties, Standards Selection, and the Control of Market Power, in Antitrust Law Journal, 2005, 10. 


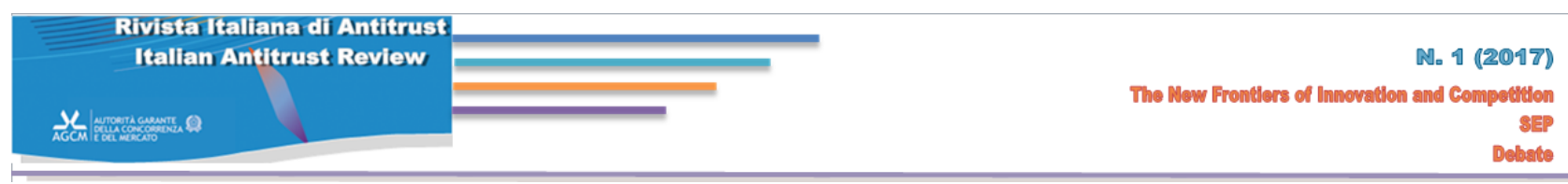

would undermine the goals of the FRAND commitment ${ }^{50}$. Similar ex ante approaches have been endorsed by the Federal Trade Commission $^{51}$, the European Commission ${ }^{52}$ and, most recently, within the IEEE Bylaws ${ }^{53}$.

The ex ante approach provides a first benchmark for what constitutes a FRAND royalty. In simple terms, the ex ante approach points to the reasonable royalty that the SEP holder could have obtained in an arms-length hypothetical negotiation with the prospective implementer just before the standard was

${ }^{50}$ M. Lemley, C. SHAPIRO, A Simple Approach to Setting Reasonable Royalties for Standard-Essential Patents, in Berkeley Technology Law Journal, 2013, 1148.

${ }^{51}$ Federal Trade Commission, The Evolving IP Marketplace, Aligning Patent Notice and Remedies with Competition, March 2011, available at https://www.ftc.gov/reports/, suggest "Courts should apply the bypothetical negotiation framework to determine reasonable royalty damages for a patent subject to a $R A N D$ commitment. Courts should cap the royalty at the incremental value of the patented technology over alternatives available at the time the standard was chosen".

${ }^{52}$ European Commission, Guidelines on the applicability of Article 101 of the Treaty on the Functioning of the European Union to horizontal co-operation agreements, of 14 January 2011, 61, suggesting that "[i] $n$ case of a dispute, the assessment of whether fees charged for access to IPR in the standard-setting context are unfair or unreasonable should be based on whether the fees bear a reasonable relationship to the economic value of the IPR (1). In general, there are various methods available to make this assessment. [...], it may be possible to compare the licensing fees charged by the company in question for the relevant patents in a competitive environment before the industry has been locked into the standard (ex ante) with those charged after the industry has been locked in (ex post). This assumes that the comparison can be made in a consistent and reliable manner".

${ }^{53}$ IEEE Bylaws (fn. 42 above): “Reasonable Rate' shall mean appropriate compensation to the patent holder for the practice of an Essential Patent Claim excluding the value, if any, resulting from the inclusion of that Essential Patent Claim's technology in the IEEE Standard'. adopted, whereas the adoption of the standard flags the ex post moment, when the patent has been included in the standard, thus gaining monopolistic added-value. The assumption is that the ex ante royalty would reflect the intrinsic value of the patent in a competitive environment.

In addition to that, it should be noted that most theoretical contributions adopting the ex ante approach further argue that the reasonable royalty for a SEP should also be capped to the incremental value of that patent over the next-best technological alternative before the standardization ${ }^{54}$.

If the general principles of the ex ante approach are rather straightforward, a number of issues have arisen in their practical implementation ${ }^{55}$. In particular, whereas some have argued that capping the FRAND rate to the incremental value, although theoretically sound, may lack to borrow from Justice Robart in Motorola -

\footnotetext{
${ }^{54}$ M. LEMLEY, C. Shapiro, fn. 50 above; J. FARrell, J. Hayes, C. Shapiro, T, Sullivan, Standard Setting, Patents, and Hold-Up, in Antitrust Law Journal, 2007, 603. The authors explain their position by way of the following example: "consider the choice between a patented production technology and an unpatented alternative. The two technologies yield the same output, so the technology user simply seeks to minimize cost. Suppose that the patented technology requires the user to bear costs of $\$ 40$, not including any royalty, and the alternative technology requires the user to bear costs of $\$ 50$. The user would be willing to pay a royalty of up to the patented technology's inherent advantage of \$10. This inherent advantage typically allows the patent holder profitably to charge a positive price (more generally, a price above marginal cost), perhaps $\$ 6$ in this example". In this (oversimplified) case the incremental value is set at $\$ 10$. This amount should constitute the benchmark for the maximum reasonable royalty.
}

${ }^{55}$ Cf. also J. FAull, A. NiKPay, The EU Law of Competition, Oxford, Oxford U. P., 2014, paragraph 4.775-4780. 


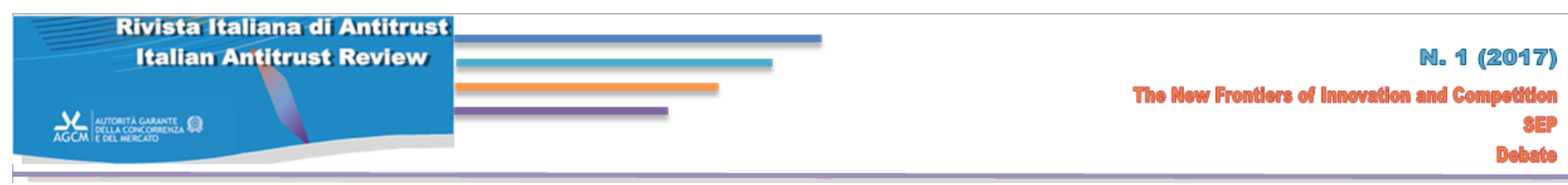

"real-world applicability", others, like Sidak and Geradin, have contended that to limit the SEP holder's remuneration to its incremental value could substantially undermine its investments and deter from further participation in the standard-setting process in the future ${ }^{56}$.

From our perspective, however, adopting an $e x$ ante evaluation of the SEPs at stake is fundamental for determining a "reasonable" licensing rate. Given the underlying principle that the FRAND royalty must be appropriate

56 As to the first objection, the prerequisite for assessing the incremental value of a technology over its next-best alternative is that there was, at the very outset, an available alternative. Lacking a valid alternative, it may be questioned if the "incremental value" criterion would still hold. Besides, some have suggested also that "if two technologies have different values it is not clear whether they actually qualify as true alternatives" (D. GERADIN, Pricing abuses by essential patent holders in a standard-setting context: $A$ view from Europe, paper prepared for the "The Remedies for Dominant Firm Misconduct" Conference June 4-5, 2008 - University of Virginia, available at

https://papers.ssrn.com/sol3/papers.cfm?abstract_id=1 174922) that the determination of technological value is an inherently subjective one and that the factors to be taken into account would be too complex (A. LAYNEFARRAR, G. LLOBET, Moving beyond simple examples: Assessing the incremental value rule within standards, in International Journal of Industrial Organization, 2014, 57). As to the second objection, Geradin argued that, even assuming that the incremental value can be calculated, due to the underlying economic model, "the rate that would have prevailed ex ante could indeed be equal to - or at least near zero", being that it only reflects a competitive outcome: "To take a trivial example, if customer $A$ buys shampoo $X$ rather than shampoo $Y$, which is a close alternative, $A$ will not pay the incremental value between $X$ and $Y$, but rather the full price of $X$, ostensibly reflecting the average value of using shampoo $X$ " (D. GERADIN, fn. Errore. Il segnalibro non è definito. above). According to this author, a royalty rate that was limited to the incremental value of the standardized technology would often fail to adequately compensate the SEP holder.) and not maximised, it seems rather logical to cap the reasonable royalty to the intrinsic value of the patent before it acquires hold-up power following its inclusion in the standard. And while we believe that a determination of FRAND royalties should point towards the patent's incremental value, we also believe that this rule is to be applied only when and if, given the specific circumstances of the case, it is reasonable to get involved in such analysis (such as: there are/were alternative and comparable technologies, providing similar added-value, and so forth $)^{57}$.

\subsection{Looking at the overall licensing scenario. The issue of royalty-stacking}

Finally, since it is widely acknowledged that the sheer number of SEPs in the ICT context and, more generally, in the electronics industry is very high ${ }^{58}$, authors, courts and regulatory bodies suggested that there are serious chances for implementers to be burdened by a "stack" of royalty demands. Said aggregate royalty may exceed a reasonable portion of the product's value, crippling its market and/or hindering the

${ }^{57}$ Along the lines of A. LAYNE-FARRAR, G. LLOBET (fn. Errore. Il segnalibro non è definito. above).

58 A quick look at the ETSI database would account for 195.038 SEPs, cf. https://ipr.etsi.org/; whether other sources point to anything in between 100.000 to 345.000 SEPs. Although these numbers should be "purified" by taking into account patent families, divisional patents (and similar instruments), as well as double-counting issues in the database, the number of SEPs that may come into play for a single product is noteworthy. For a judicial determination of the relevant SEPs in 2G/3G/4G standards see EWHC decision in Unwired Planet (fn. 38 above), \$ 377, suggesting, for instance, that the "purified" 4G/LTE pool includes 800 patents. 


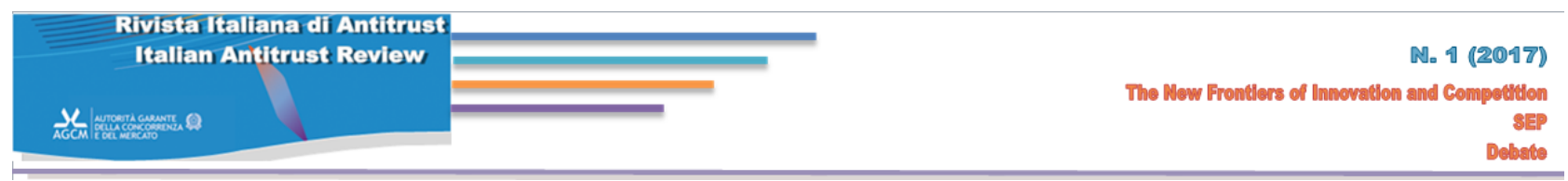

adoption of the standard altogether ${ }^{59}$. For instance, an interesting empirical research conducted in 2014 came to the conclusion that the potential royalty demand over a $\$ 400$ smartphone amounted to $\$ 120$, i.e. $30 \%$ of the end product's price (and nearly equal to the cost of the device's components) ${ }^{60}$.

An occurrence of so-called "royalty stacking" clashes with the very concept of FRAND, as it cannot be deemed to be fair, nor reasonable, for the aggregate licensing fees to make "commercialisation of products compliant to the standard uneconomical or unprofitable",61. Lemley and Shapiro suggest that the "royalty stacking" existence would exacerbate the hold-up issue by multiplying the chances for an implementer to face infringement claims and supracompetitive price demands ${ }^{62}$. And yet, the possibility of a "royalty stacking" would not be the sole responsibility of the individual SEP holder, but rather of all the SEP holders for the standard at stake.

A number of decisions rendered in the US have recognized the potential harm caused by royalty

\footnotetext{
${ }^{59}$ See the seminal contribution by M. LEMLEY, C. SHAPIRO, Patent Holdup and Royalty Stacking, in Texas Law Review, 2007, 1991.
}

${ }^{60}$ A. Armstrong, J. Mueller, T. Syrett, The Smartphone Royalty Stack: Surveying Royalty Demands for the Components Within Modern Smartphones, Available at https://www.wilmerhale.com/pages/publicationsandne wsdetail.aspx?NewsPubId=17179872441

${ }^{61}$ See A. LAYNE-FARRAR, The Economics of FRAND, forthcoming in Antitrust Intellectual Property and High Tech Handbook, Cambridge U. P., (D. Sokol ed.) available at SSRN: https://ssrn.com/abstract=2725959;

${ }^{62}$ M. Lemley, C. Shapiro, Patent Holdup and royalty staking, cit., at 2011 stacking issues. Most notoriously in the 2013 Microsoft v. Motorola case, Judge Robart held that "a proper methodology for determining a RAND royalty should address the risk of royalty stacking by considering the aggregate royalties that would apply if other SEP holders made royalty demands of the implementer", and that the potential for royalty stacking should be taken into account by SEP holders $^{63}$. Similar opinions have been supported by the European Commission ${ }^{64}$, the DoJ and the FTC ${ }^{65}$ and, most recently, by the Competition Commission of India (CCI), which pointed out to the fact that "FRAND licenses are primarily intended to prevent patent bold up and royalty stacking" ${ }^{\prime 66}$.

However, while it can reasonably be held that if hundreds, if not thousands of patents, insist on a single product, the occurrence of royalty stacking is - to say the least - likely, on the other hand it must be recognized that there are

\footnotetext{
${ }^{63}$ Microsoft v. Motorola, \ 72; position subsequently taken up by Judge Holderman in In re Innovatio (below, fn. 70).

${ }^{64}$ See the report sponsored by the Joint Research Centre (at http://is.jrc.europa.eu/pages/ISG/EURIPIDIS/docum ents/05.FRANDreport.pdf), written by Y. MÉNIÈRE with the title Fair, Reasonable and NonDiscriminatory(FRAND) Licensing Terms, Research analysis of a Controversial Concept.

${ }^{65}$ US Dept. of Justice and Federal Trade Commission, Antitrust Enforcement and Intellectual Property Rights: Promoting Innovation and Competition, Washington D.C., 2007, 61 .

${ }^{66}$ See e.g. Best IT World (India) Private Ltd v.Telefonaktiebolaget LM Ericsson, case n. 4/2015, Competition Commission of India (May 12, 2015) available at:

http://www.cci.gov.in/May2011/OrderOfCommission/ 261/042015.pdf.
} 


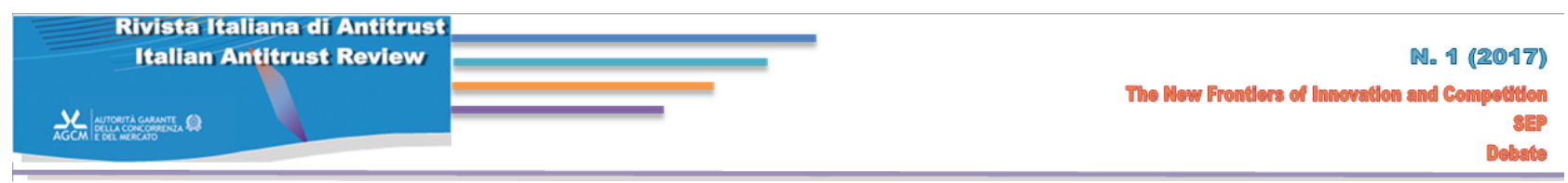

cases where the potential for a royalty stack may be neutralized by way of cross-licensing, lowered prices, patent exhaustion, and so on. Thus, the US Federal Circuit in the Ericsson v. D-Link decision correctly argued that, while "royalty staking may be a potential problem posed by SEPs, the defendants [should] present evidence of an actual royalty stack, which [cannot] simply assumed to be present ${ }^{\prime 67}$.

In light of the above, when determining FRAND licensing terms, the parties should duly take into account the context in which the royalty is to be negotiated. SEP negotiations do not take place in a vacuum: most standards have been in place for years, and are only gradually changed, within time. Therefore, the parties - and especially the patentee - should rely on the available information on the overall licensing scenario. Along this lines, the IEEE recently updated bylaws suggest that the reasonable rate's determination shall include the consideration of "the value that the Essential Patent Claim contributes [...] in light of the value contributed by all Essential Patent Claims for the same IEEE standard practiced in that Compliant Implementation" ${ }^{68}$.

\subsection{Top-down approach}

Finally, in the current lack of any consolidated method for determining FRAND royalties, two recent decision from US and UK courts

\footnotetext{
${ }^{67}$ See Ericsson Inc. v. D-Link Systems Inc., 773 F.3d 1201 (2014): "The mere fact that thousands of patents are declared to be essential to a standard does not mean that a standard-compliant company will necessarily have to pay a royalty to each SEP holder".

68 IEEE Bylaws (fn. 42 above), 16.
}

adopted a new approach that seems to grasp the complexities of the matter while abiding (at least partially) to the principles we have set out above: the so-called "top down" approach. In a nutshell, the "top-down" method starts with the determination of the maximum aggregated royalty that may be asked to an implementer for a specific standard and/or piece of technology and then divides this amount for the number of SEPs at issue. By adopting the "top-down" approach, the single SEP holder may only ask for a fraction of the "capped" royalty, thus preventing - at the outset - the risk of excessive royalty stacking and indirectly lowering the risks of excessive ex post pricings and the burden of non-implemented patents ${ }^{69}$.

In particular, in the US decision In re Innovatio, Judge Holderman suggests that the "top down" method "best approximates the $[\mathrm{F}] \mathrm{R} A N D$ rate that the parties to a hypothetical ex ante negotiation would have agreed upon"70. The "top down" approach, as construed in In re Innovatio, first considers the average price of the product that uses a patent (in this particular case, a Wi-Fi connection chip). By reference to the average price of the implementing device, the Judge then calculates the average profit margin from the sale of each product, isolating a share of profit on which

\footnotetext{
${ }^{69}$ M. FRANZOSI (Royalty per uso di brevetto standard: but for, Giorgia Pacific, apportionment, in Riv. dir. ind., 2015, I, 259) adjusts the principle of apportionment to the essential patent dynamics and proposes a calculation using a total royalty (i.e. a ' $c a p$ ') on the whole product, which total should be then divided (indeed, apportioned) among the product's technical segments and subdivided by the number of patents pertaining to such segments.

${ }^{70}$ In re Innovatio IP ventures, LLCPatent Litigation, 2013 WL 5593609(N.D. Ill Oct 3, 2013), at 85.
} 


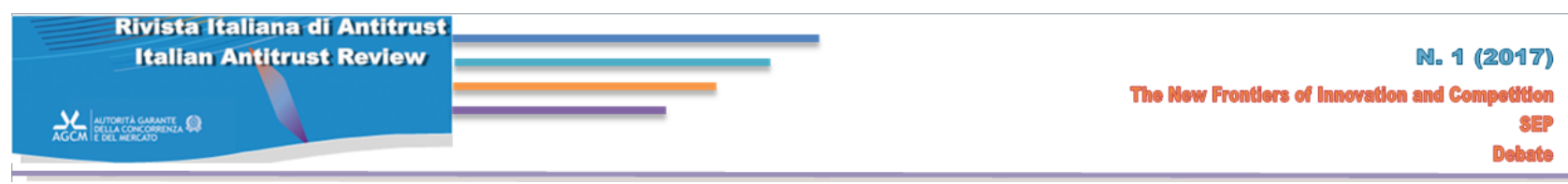

the implementer would be able to pay royalties. The average profit so determined is then multiplied by the ratio between the patents at issue and the total number of patents of the standard in question. By including the 'qualitative' factor in this calculation, i.e. the consideration that " $84 \%$ of the value in electronic patents is found in the top $10 \%$ of electronic patents" and noting that essential patents at issue were rather important for the standard, therefore falling under the said 10\%, Judge Holderman further capped, both the profit share on which to determine the royalty (to $84 \%$ of the total) and the number of SEPs to take into account for the calculation $(10 \%$ of the patents that are declared essential $)^{72}$.

On the European side, in Unwired Planet $v$. Huawei, Briss J of the High Court of England and Wales used the "top-down" approach to cross-check the FRAND royalty rate he determined using some comparable licenses that were available in the case, as they had been filed as evidence by the parties ${ }^{73}$. As Briss J put

\footnotetext{
${ }^{71}$ In re Innovatio, cit., at 85-86.

72 For the full calculation, see In re Innovatio, id: "Multiplying the average Wi-Fi chip price of $\$ 14.85$ by a profit margin of $12.1 \%$ yields an average profit of $\$ 1.80$ on each chip. That $\$ 1.80$ represents the total profit available to a chipmaker out of which to pay royalties for intellectual property. Next, the court multiplies $\$ 1.80$ by $84 \%$, the value attributable to the top $10 \%$ of 802.11 standard-essential patents, to obtain $\$ 1.51$, the value attributable to the top $10 \%$ of all 802.11 standard-essential patents. Finally, the court multiples $\$ 1.51$ by $19 / 30035$ to determine the pro rata share of the value in the top $10 \%$ of all 802.11 standard-essential patents attributable to Innovatio's nineteen-patent portfolio. The result is 9.56 cents. Accordingly, [...a] rate of 9.56 cents per $W i$-Fi chip [is the] $R A N D$ rate for licensing Innovatio's 802.11 patent portfolio".
}

${ }^{73}$ See recently published comments on the decision, J. L. CONTRERAs, A New Perspective on FRAND Royalties: it, the top-down approach "starts with a number representing what the appropriate total aggregate royalty burden [i.e. a 'cap'] should be for a given standard' a factor defined as "T". From this $T$ figure, Briss J "one can share out the royalty across all licensors in proportion to the value of each licensor's patent portfolio based on assessing that value as a share ["S"] of the total relevant patent porffolio essential to that standard". The conclusion is that "the FRAND rate [would thus be] the product of the two (TXS)".

However, Briss J did not determine the total aggregate value "T". Instead, he turned to the complex task of determining the plaintiff effective share "S" among what he defines as the "Relevant SEPs", meaning those technically essential in implementing the standard. To do so, Briss $\mathrm{J}$ took into account a number of filtering and rounding criteria, based on some of fundamental assumptions. In particular, Briss $\mathrm{J}$ allowed that in order to determine the plaintiff's share of re: (i) "counting patents" was inevitable; (ii) all patents should be considered of equal value (although technological "keystone" patent may well exist); (iii) only patent families should be accounted for; and (iv) adding up patent declared on the ETSI

\footnotetext{
Unwired Planet v. Huawei, University of Utah College of Law Research Paper No. 206, 2017, forthcoming, available at: https://ssrn.com/abstract $=2949449$, M. PATTERSON, Teasing through a single FRAND rate, in Patently-O blog, 20 April 2017, available at: https://patentlyo.com/patent/2017/04/pattersonteasing-through.html; P. PICHT, Unwired Planet/Huawei: A seminal SEP/FRAND decision from the UK, Max Planck Institute for Innovation and Competition Research Paper No. 17-07, available at: https://ssrn.com/abstract $=2967183$.
} 


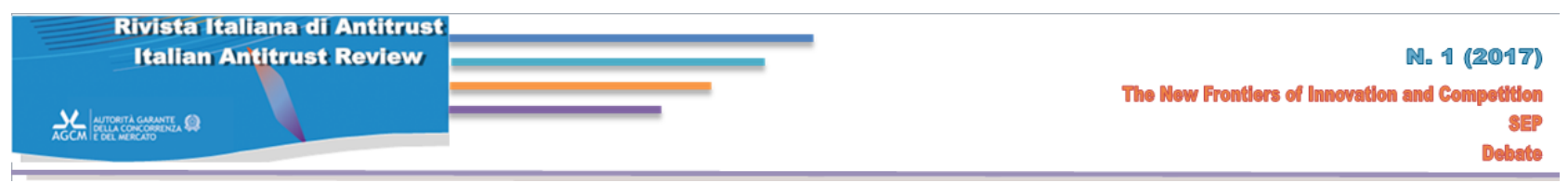

register was an inacceptable method, since "very many more patent are declared to be essential than in fact are essential'. In the end, on the basis of the evidence at hand, Briss $\mathrm{J}$ assessed that that Unwired Planet share of the total patent pool was of $0,70 \%$, that the comparable license was $0,062 \%$ of the end-product's value. By multiplying these values, Briss $\mathrm{J}$ ascertained that it "produce [d] a total royalty burden $T$ of $8.8 \%$ " of the product's price, which fell in line with the various states by individual companies in the market, many of which suggested that the total aggregated royalty should fall within a "singledigit' percentage of the handset's sales prices. However, it should be noted that a major difference between Judge Holderman's approach consists in that Briss J did not accept (nor bothered to consider, in all truth) that the "top-down" approach would reflect the ex-ante value of the patents at stake, since he substantially refuses to apply the concept in setting the foreground of the case.

All in all, both In re Innovatio and Unwired Planet v. Huawei are worth being carefully reviewed as cross-Atlantic and closely-aligned precedents, part of the international acquis we hinted at, whereby the Courts, burdened with the complex task to determine the FRAND royalty in specific disputes, decided to start from the maximum amount that may be reasonably asked to an implementer for a specific standardized technology as a whole, to then assess the share the SEP holder finally deserves by division and subtractions that variously take into account the overall licensing scenario and the chance that not all SEPs are either truly essential or mandatorily implemented ${ }^{74}$.

\footnotetext{
${ }^{74}$ As to the "ex ante approach", whereas Judge Holderman expressly adopted it in evaluating the FRAND licensing rate submitted to him, Briss J, on the contrary, was inclined to reject it on the basis of the evidence submitted by the parties' expert economists, both of whom suggested not to regard FRAND "as a scheme which meant the patentee could not appropriate some of the value that is associated with the inclusion of his technology into the standard and the value of the products that are using those standards". However, Briss J eventually allowed that "it [was] not necessary to look into that any further since neither side before me took the point', fn. 37 above, see $\int 97$.
} 


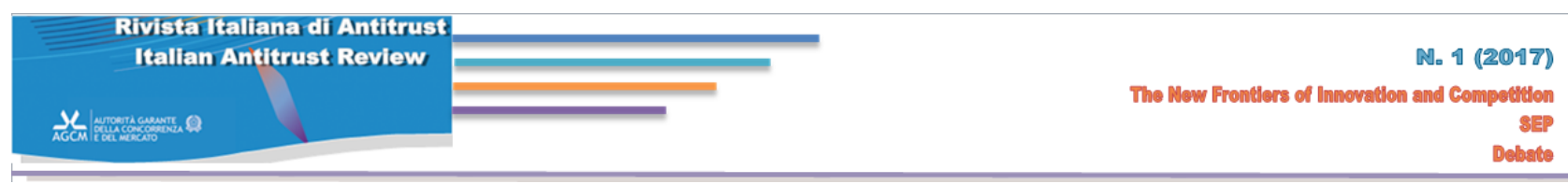

\section{BIBLIOGRAPHY}

P. Areeda, Essential facilities: an epithet in need of limiting principles, in 58 Antitrust L. J., 841 1990, 841;

E. Arezzo, Intellectual Property Rights at the Crossroad between Monopolization and Abuse of Dominant Position: American and European Approaches Compared, in The John Marshall Journal of Computer \& Information Law, 2006, 455;

A. Armstrong, J. Mueller, T. Syrett, The Smartphone Royalty Stack: Surveying Royalty Demands for the Components Within Modern Smartphones, available at:

https://www.wilmerhale.com/pages/publicati onsandnewsdetail.aspx?NewsPubId $=17179872$ 441 ;

J. C. Baron, Licensing Terms of Standard Essential Patents: A Comprehensive Analysis of Cases, JRC Science for Policy Report, EUR 208702 EN, 2017;

W. J. Baumol, The Free-Market Innovation Machine: Analyzing the Growth Miracle of Capitalism, Princeton, Princeton University Press, 2002;

R. Bekkers, A. Updegrove, IPR Policies and Practices of a Representative Group of StandardsSetting Organizations Worldwide, 2012, available at: http://ssrn.com/abstract $=2333445$;

C.V. Chien, Holding Up and Holding Out, in Michigan Telecommunication \& Technology Law Review, 2014, 1;

G. Colangelo, Il mercato dell'innovarione: brevetti, standards e antitrust, in Quaderni di Giurisprudenza Commerciale, 397, 2016;
J. L. Contreras, A New Perspective on FRAND Royalties: Unwired Planet v. Huawei, University of Utah College of Law Research Paper No. 206, 2017, forthcoming, available at: https://ssrn.com/abstract=2949449;

T. Cotter, The Comparative Law and Economics of Standard Essential Patents and FRAND Royalties, in 22 Texas Intellectual Property Law Journal, 2014, 311 ;

B. Doherty, Just what are essential facilities?, in 38 Common Market Law Review, 2001, 397;

European Commission, Standard Essential Patents for a European Digitalised Economy, Ares(2017)1906931, 10 April 2017, available at: https://ec.europa.eu/info/law/betterregulation/initiatives/ares-2017-1906931_en;

S. B. Evrard, Essential facilities in the European Union: Bronner and beyond, in 10 Columbia Journal of European Law, 2004, 1;

J. Farrell, J. Hayes, C. Shapiro, T, Sullivan, Standard Setting, Patents, and Hold-Up, in Antitrust Law Journal, 2007, 603;

J. Faull, A. Nikpay, The EU Law of Competition, Oxford, Oxford U. P., 2014;

R. Feldman, Ending Patent Exceptionalism and Structuring the Rule of Reason: The Supreme Court Opens the Door for Both, in 15 Minn. J.L. Sci \& Tech, 2014, 61, 68;

E. Fox, Chairman Miller, the Federal Trade Commission, Economics, and Rashomon, in Law and Contemporary Problems, 1987, 33;

A. Galetovic, S. Haber, R. Levine, An empirical examination of patent holdup, in Journal of Competition Law \& Economics, 2015, 1; 


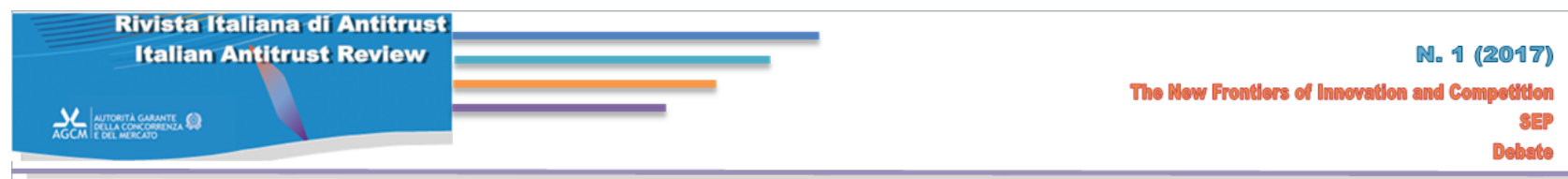

D. Geradin, Pricing abuses by essential patent holders in a standard-setting context: A view from Europe, paper prepared for the "The Remedies for Dominant Firm Misconduct" Conference June 4-5, 2008, University of Virginia, available at https://papers.ssrn.com/sol3/papers.cfm?abst ract_id=1174922;

R. Grasso, Standard Essential Patents: Royalty Determination in the Supply Chain, in Journal of European Competition Law \& Practice, 2017, vol. 8 , No. 5, 283;

H. Hovenkamp, Competition in Information Technologies: Standard-Essential Patents, nonpracticing entities and FRAND bidding, in University of Iowa Legal Studies Research Paper, No. 12-32, 12, available at

https://papers.ssrn.com/sol3/papers.cfm?abst ract_id=2154203;

T. Kaseberg, Intellectual Property, Antitrust and Cumulative Innovation in the EU and the US, Hart, 2012, 219;

J. P. Kesan, C. M. Hayes, FRAND's Forever: Standards, Patent Transfers, and Licensing Commitments, in Indiana Law Journal, 2014, 241;

K. Kwok, A New Approach to Resolving Refusal to License Intellectual Property Rights Disputes, in World Competition, 2011, 261;

A. Layne-Farrar, The Economics of FRAND, forthcoming in Antitrust Intellectual Property and High Tech Handbook, Cambridge U. P., (D. Sokol ed.) available at SSRN:

https://ssrn.com/abstract $=2725959$;

A. Layne-Farrar, G. Llobet, Moving beyond simple examples: Assessing the incremental value rule within standards, in International Journal of Industrial Organization, 2014, 57;
J. Lee, Implementing the Frand Standard in China, in Vand. J.Ent \& Tech. L., 2016, 37;

M. Lemley, C. Shapiro, A Simple Approach to Setting Reasonable Royalties for Standard-Essential Patents, in Berkeley Technology Law Journal, 2013, 1148;

M. Lemley, C. Shapiro, Patent hold-up and royalty stacking, in Texas Law Review, vol. 85, 2007, 1991;

J. Lerner, J. Tirole, Standard-Essential Patents, in Journal of Political Economy, 2015, vol. 123, no. 3, available at:

http://www.journals.uchicago.edu/doi/citedby /10.1086/680995;

Y.B. Li, Antitrust Correction for Qualcomm's SEPs Package, Licensing and Its Flexibility in China, in IIC, 2016, 336;

B. Lundqvist, The rise of standardisation and the limits to self-governance': unilateral conduct under international standards from an EU competition law perspective, in T. Riis (ed.), User Generated Law, Cheltenham, Edward Elgar, 2016, 180;

R. P. Merges, J. M. Kuhn, An Estoppel Doctrine for Patented Standards, 97 California Law Review, 2009, 28;

J. M. Pardessus, Traité des servitudes on services fonciers, Bruxelles, 1840;

M. Patterson, Teasing Through a Single FRAND Rate, in Patently-O blog, 20, April 2017, available at: https://patentlyo.com/patent/2017/04/patter sonteasing-through.html;

C. Pentheroudakis, J. A. Baron, Licensing Terms of Standard Essential Patents. A Comprehensive Analysis of Cases, in JRC Science for Policy Report, EUR 28302 EN, available at: 


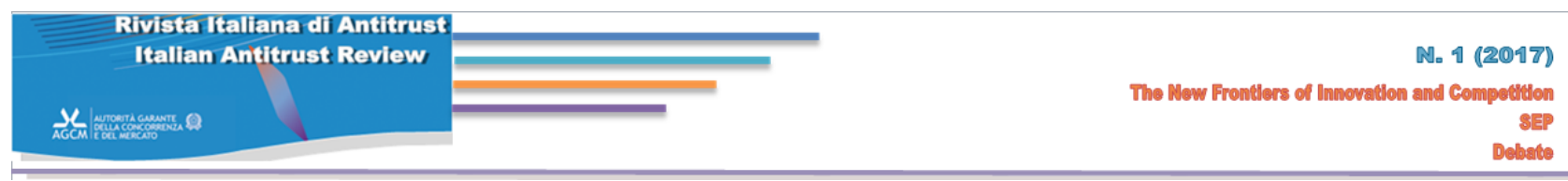

https:/ / ec.europa.eu/jrc/en/publication/eurscientific-and-technical-researchreports/licensing-terms-standard-essentialpatents-comprehensive-analysis-cases;

R. Peritz, The Competition Question Unasked in Actavis: What Is the Scope of the Patent Right to Exclude?, in 28 Antitrust, 2013, 48.

P. Picht, Unwired Planet/Huawei: A seminal SEP/FRAND decision from the UK, Max Planck Institute for Innovation and Competition Research Paper No. 17-07, available at: https:/ / ssrn.com/abstract=2967183;

R. Pitofsky, D. Patterson, J. Hooks, The essential facilities doctrine under U.S. antitrust law, in 70 Antitrust Law Journal, 2002, 443;

G. Sena, Note paradossali sulla proprietà intellettuale, in Studi di diritto industriale in onore di Adriano V anzetti, Giuffrè, Milan, 2004, II, 1533, 1534;

D. Sokol, W. Zheng, FRAND in China, in Tex. Intell. Prop. L.J., 2013-2014, 71;

D. Swanson, W. Baumol, Reasonable and Nondiscriminatory (RAND) Royalties, Standards Selection, and the Control of Market Power, in Antitrust Law Journal, 2005, 10;

V. Torti, Intellectual Property Rights and Competition in Standard Setting-Objectives and Tensions, Routledge, 2016;

H. Ullrich, FRAND Access to open standards and the patent exclusivity: Restating the principles, Max Planck Institute for Innovation \& Competition Research Paper No. 17-04, 2017, available at: https://ssrn.com/abstract=2920660;

R. Viswanath, Demystifying the Indian FRAND Regime: The Interplay of Competition and Intellectual
Property, in Journal of Intellectual Property Rights, 2016, 90;

S.W. Waller, B.M. Frischmann, Revitalizing essential facilities, in 75 Antitrust Law Journal, 2008, 1. 